\title{
Triple helix DNA model : Relationship in multicultural characteristic of three Southern borders of Thailand
}

\author{
Suparaporn Tuannoi ${ }^{1 *}$, Yanin Rugwongwan ${ }^{2}$ \\ ${ }^{1}$ Faculty of Communication Sciences, Prince of Songkla University, Pattani, Thailand \\ 2 Multidisciplinary Design Research, Faculty of Architecture, King Mongkut's Institute of Technology Ladkrabang, \\ Bangkok, Thailand
}

\author{
Keywords \\ Cultural competence \\ Bridging multicultural gaps \\ Multicultural characteristics \\ Three Southern \\ Borders of Thailand
}

Received: 7 June 2020 Accepted: 17 November 2020 Published: 12 December 2020

\begin{abstract}
Three Southern borders of Thailand are a multicultural society that consists of relationships among three main cultures including Thai-Buddhist, Thai-Muslim, and Thai-Chinese. The unrest has occurred for more than fifteen years which many parties have tried to solve the problem. The understanding was developed from a concept study of multicultural competence. The objectives of this research were included 1) the study of the relationship of acculturation, and 2) the synthesis elements of the Characteristics in three Southern borders of Thailand through theories of Melting Pots and Salad Bowls. The research study is a qualitative method that thirties of past and present secondary data that were connected to cultural relations in three Southern borders of Thailand. Additionally, primary information from ten different cultural people who lived in this area was gathered through in-depth interviewing. The results showed that 1) the relationship of acculturation were divided in four aspects that included the deep cultural identity, the two cultural blending, the three cultural integrating, and the cultural sensitivity, and 2) the synthesis elements of the Multicultural Characteristics in three Southern borders of Thailand revealed that it was the triple-stranded Deoxyribonucleic Acid (DNA) of the existent three cultures. They were connected through Melting Pots theory in two cultural blending and three cultural integrating i.e., cuisine, clothing, medication, architecture, occupation, tourist attraction, and recreation while Salad Bowl theory influenced deep cultural identities, such as religious days and religious rites. However, there was a gap between cultures which was part of the cultural sensitivity, for example, the appropriate behavior in the different religious ceremonies that the understanding should be established to connect the triple helix DNA cultures. The results were the research framework that could be applied in the communication process for bridging the gap between multicultural in three Southern borders of Thailand.
\end{abstract}

(C) 2020 The Author(s). Published by TAF Publishing

\section{INTRODUCTION}

The unrest in the three southern borders of Thailand, consisting of Pattani province, Yala province, and Narathiwat province, has continued since 2004 . The disturbance decreasing since 2013, according to instability data in three southern border provinces around 2015 (Deep South Incident Database, 2016). There is still the loss of life and property to both government officials and people in the area. Many organizations have found ways to reduce conflicts in the area in terms of the policy as learning to accept differences diversity in a multicultural society, traditions, ways of life, beliefs, and promoting coexistence in society. Multiracialism consisting of Thai-Buddhism, Thai-Muslim, and Thai-Chinese. Studying the needs of people in the three southern border provinces (College of Islamic Studies Prince of Songkla University, and Yala Islamic College, 2005) found in nine dimensions include politics and governance, society, economy, education, religion, culture, lifestyle, environment, and public health. Four needs as follows as the need for participation, accepting cultural diversity, the need

\footnotetext{
* corresponding author: Suparaporn Tuannoi

†email: aewsri3@hotmail.com
} 
for justice and equality, and to concede the unique identity of the people in the area. The management of the conflict is using non-violent methods (Charoenwattana \& Renumas, 2017; Pan \& Lu, 2019). Establish and understanding the relationship is satisfying all parties concur or stepping through the original conceptual framework and will enable the process to set on together. In the neighborhood, the upper part of Malaysia, which has similar characteristics to the three southern borders of Thailand. The familiar identity concept used to communicate positively between the Malay people of Thai descent and Malay descent (Oraphan, 2008). The study of the characteristic of three southern borders of Thailand as a guideline in determine conflicts in the area. The objectives of this research were included 1) the study of the relationship of acculturation, and 2) the synthesis elements of the Characteristics in three Southern borders of Thailand. The discovery of cultural characteristics in three southern borders of Thailand will contribute to solving the problem. The research study is the thirty qualitative methods of past and present information linked to cultural relations in the three southern border provinces of Thailand. Besides, preliminary data from ten different cultural people who live in this area are gathered through in-depth interviews.

\section{LITERATURE REVIEW Concept of Culture}

Culture made up of visible culture and invisible culture based on the iceberg concept of culture (Hall, 1989; Weng \& Yang, 2016). The visible culture like a surface of the culture iceberg such as food, music, clothing, language, visual arts, festivals, literature, performing arts, games, and decorations physical, etc., and invisible culture is a deep culture such as religious beliefs, value, norm, the importance of space, attitudes, etc. There are the same as culture in the three southern borders of Thailand have both surface culture and deep culture between multicultural. The event in three southern borders that focus on the three cultures, such as the 3 Culture Summit in Narathiwat province, which is held continuously every year by participating in food shows in the area and distributed at the event. As well as The Lim ko niao festival with of Immaculate conception with three civilized art shows, ancient city decorations three cultures, rally activities three communities three cultures, three ancient indigenous food cultures.

Although there is a focus on the expression of three collectors as a symbolic structure still lack the understanding of cultural convergence and the use of symbols of religious landmarks and color instead of images of each culture (Figure 1).
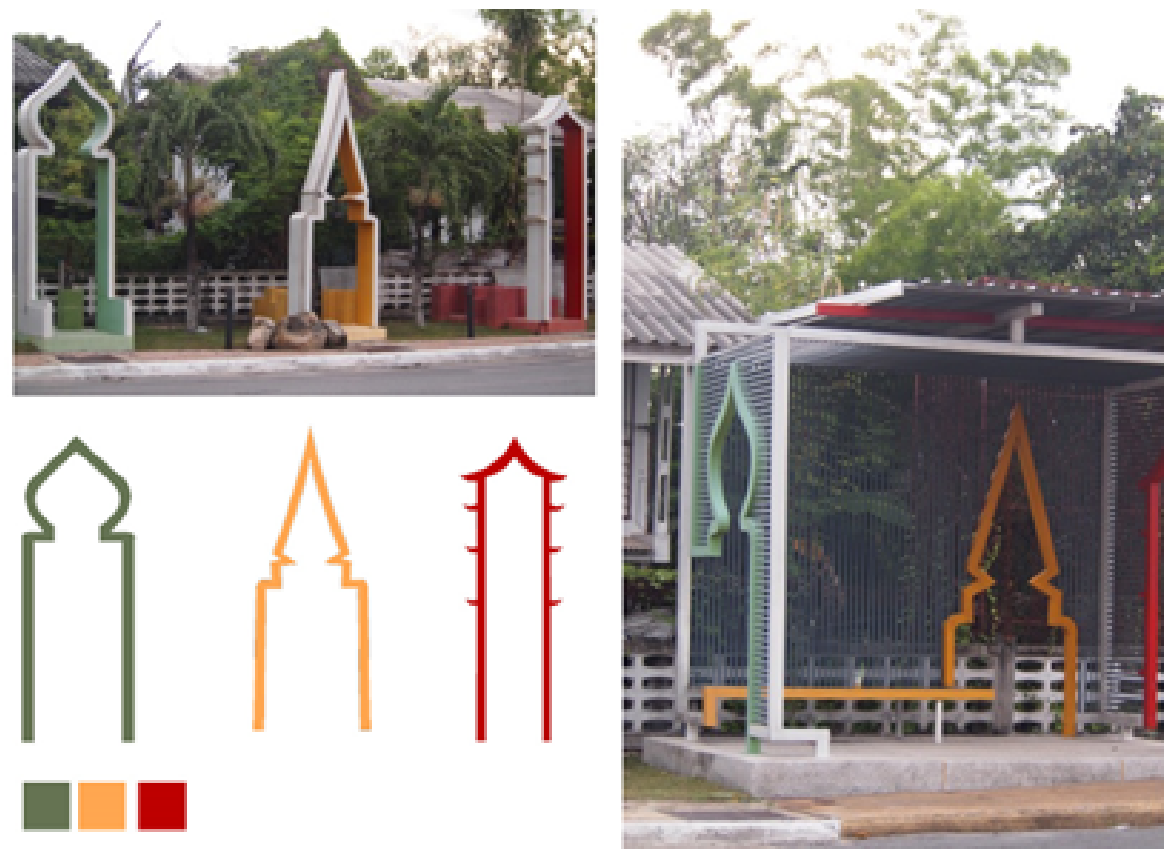

FIGURE 1. Bus stops showing multiculturalism in the three southern borders of Thailand

\section{Melting Pots \& Salad Bowls Theory}

The melting pots Theory used to describe the melting cultures that migrated to the United States that merged cultures into Americans during the first immigration period (Berray, 2019; Chou, Wu, \& Chou, 2017) like a metal heat high smelting. The combination of many cultures has led to new cultures. Salad Bowls' Theory contradicts the idea of assimilating each culture that has migrated to America that each culture has own identity and maintain its (Figure 2). 


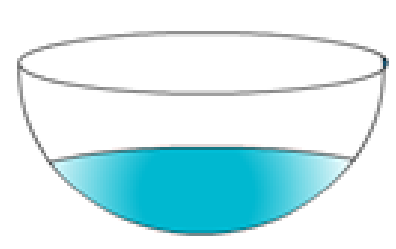

The melting pots

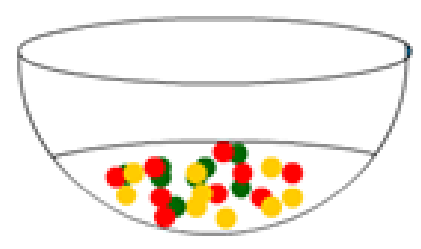

Salad Bowls

FIGURE 2. Features of melting pots \& salad bowls theory (Berray, 2019)

\section{METHODOLOGY}

This research is a qualitative research method that thirties from the past to the present secondary data collection based on documents and research related to the relationship between multiculturalism in the three southern borders of Thailand. Analyze and enumerate the combination of both the visible and the invisible culture of both Thai- Buddhist, Thai- Muslim, and Thai-Chinese (Table 1).

All the data are analyzed and categorized to concept mapping. The data groups divided into two main parts, which are cultural integration and deeply cultural (Figure 3).

TABLE 1. Data collection of the multiculturalism relationship in three southern borders of Thailand

\begin{tabular}{|c|c|c|c|c|c|c|}
\hline \multirow[t]{2}{*}{ Document and Research } & \multirow{2}{*}{$\begin{array}{l}\text { Deep Cul- } \\
\text { tural Iden- } \\
\text { tity }\end{array}$} & \multicolumn{3}{|c|}{ The Two Cultural Integrating } & \multirow{2}{*}{$\begin{array}{l}\text { The Three } \\
\text { Cultural } \\
\text { Inte- } \\
\text { grating }\end{array}$} & \multirow{2}{*}{$\begin{array}{l}\text { The Cul } \\
\text { tural } \\
\text { Sensitivity }\end{array}$} \\
\hline & & $\begin{array}{l}\text { Buddhism } \\
\text { \& Muslim }\end{array}$ & $\begin{array}{l}\text { Muslim } \\
\text { \&Chinese }\end{array}$ & $\begin{array}{l}\text { Chinese \& } \\
\text { Buddhism }\end{array}$ & & \\
\hline Duangchan (1984) & & & $\checkmark$ & & $\checkmark$ & \\
\hline Phongphaw (1985) & $\checkmark$ & & & & & $\checkmark$ \\
\hline Laosat (1987) & & $\checkmark$ & & & & \\
\hline Watthanakun (1994) & $\checkmark$ & & & & & $\checkmark$ \\
\hline Ammaphan (1998) & & & & & $\checkmark$ & \\
\hline Sariming (1998) & $\checkmark$ & & & & & \\
\hline Kitthavorn (2004) & & $\checkmark$ & & & & $\checkmark$ \\
\hline Lohajinda (2004) & & & & & $\checkmark$ & \\
\hline Sirisakdamkeong (2004) & $\checkmark$ & & & & & $\checkmark$ \\
\hline (Thepsuriwong, 2004) & $\checkmark$ & & & & & \\
\hline (Thepsuriwong \& Buakwan, 2004) & & $\checkmark$ & & & & \\
\hline (Eksaphan, Intararak, Phatyaiying, \& Wongmontha, 2005) & $\checkmark$ & & & & & \\
\hline Meenium et al. (2005) & $\checkmark$ & $\checkmark$ & $\checkmark$ & $\checkmark$ & $\checkmark$ & \\
\hline Pinyomak (2005) & $\checkmark$ & & & & & $\checkmark$ \\
\hline $\begin{array}{l}\text { College of Islamic Studies Prince of Songkla University, and Yala Is- } \\
\text { lamic College (2005) }\end{array}$ & & & & & $\checkmark$ & $\checkmark$ \\
\hline Haryeeyahama and Punyaburana (2006) & & $\checkmark$ & $\checkmark$ & $\checkmark$ & $\checkmark$ & \\
\hline $\begin{array}{l}\text { Rattanamanee, Lohajinda, Hayeehama, Punyaburana, and Saengnin } \\
\text { (2007) }\end{array}$ & $\checkmark$ & $\checkmark$ & $\checkmark$ & $\checkmark$ & $\checkmark$ & \\
\hline $\begin{array}{l}\text { Wiboonma, Lohajinda, Hayeehama, Rattanamanee, and Punyaburana } \\
\text { (2007s) }\end{array}$ & $\checkmark$ & $\checkmark$ & $\checkmark$ & $\checkmark$ & $\checkmark$ & $\checkmark$ \\
\hline Oraphan (2008) & & $\checkmark$ & & & & \\
\hline Sirisakdamkeong (2009) & $\checkmark$ & $\checkmark$ & $\checkmark$ & $\checkmark$ & $\checkmark$ & $\checkmark$ \\
\hline Attharatsathien (2010b) & & $\checkmark$ & & & & \\
\hline Wiboonma et al. (2007s) & $\checkmark$ & $\checkmark$ & $\checkmark$ & $\checkmark$ & $\checkmark$ & $\checkmark$ \\
\hline Oraphan (2008) & & $\checkmark$ & & & & \\
\hline Sirisakdamkeong (2009) & $\checkmark$ & $\checkmark$ & $\checkmark$ & $\checkmark$ & $\checkmark$ & $\checkmark$ \\
\hline Attharatsathien (2010a) & & $\checkmark$ & & & & \\
\hline Attharatsathien (2010b) & & $\checkmark$ & $\checkmark$ & $\checkmark$ & $\checkmark$ & \\
\hline Rueangnarong (2010) & & $\checkmark$ & & & & \\
\hline Kaewnuy (2013) & $\checkmark$ & $\checkmark$ & & & $\checkmark$ & \\
\hline Phromwiset (2013) & $\checkmark$ & & & & & \\
\hline Duerae (2015) & & & & & & $\checkmark$ \\
\hline Wongmondta (2015b) & & & & & $\checkmark$ & \\
\hline Wongmondta (2015a) & & $\checkmark$ & & & & $\checkmark$ \\
\hline Muhamad (2016) & $\checkmark$ & & & & & \\
\hline Tepsing and Bunprakarn (2016) & $\checkmark$ & & & & & \\
\hline
\end{tabular}




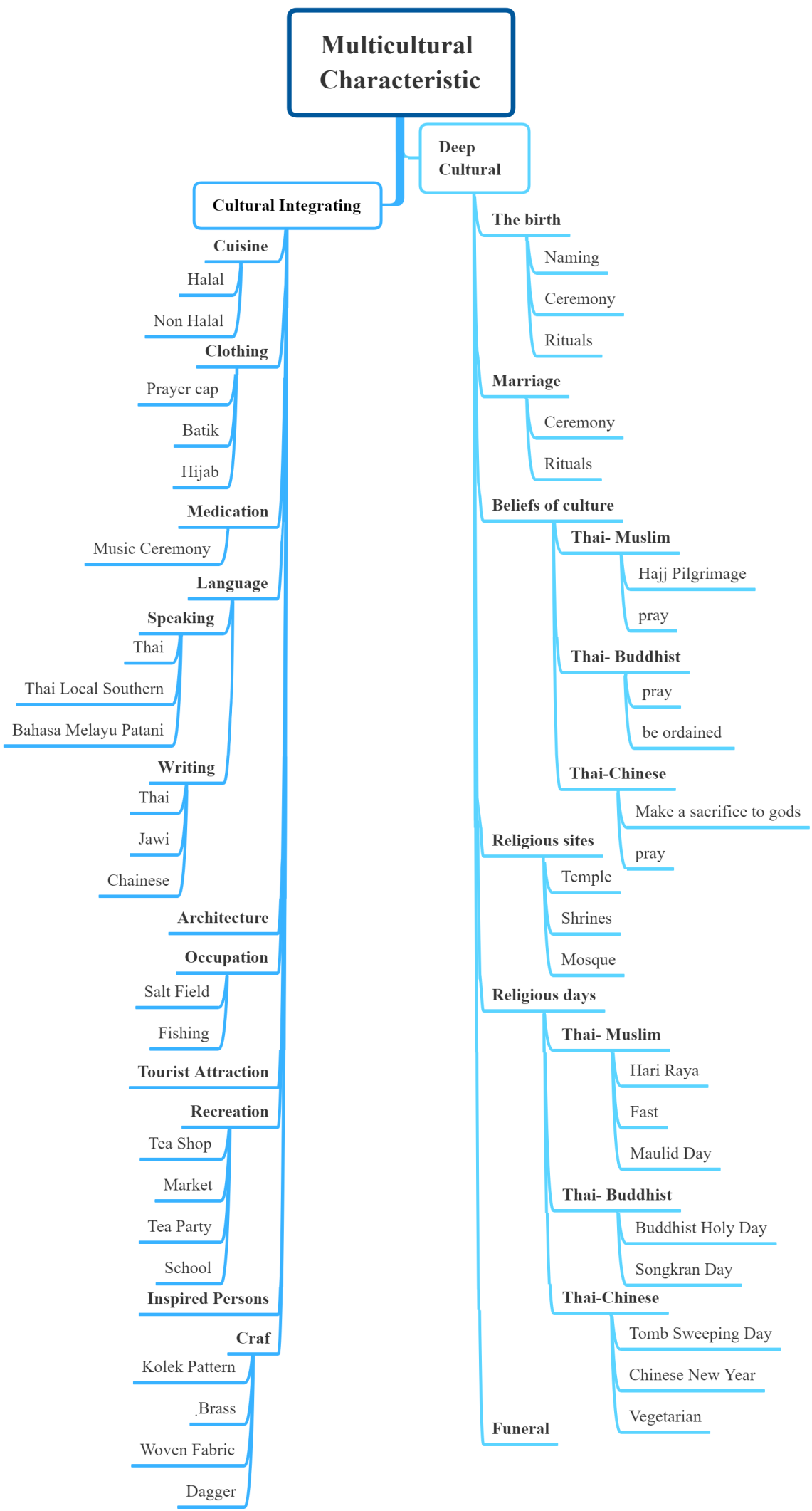

FIGURE 3. Multicultural characteristic mapping

Additionally, primary information from ten different cultural people who lived in this area was gathered through in-depth interviewing in the cultural competency. Data pro- vided a similar massage that are some different parts of the group of Thai-Muslims that cannot participate in some other ceremony but understanding in other (Table 2). 
TABLE 2. The massage from key informants

\begin{tabular}{ll}
\hline \hline Key Informants & The Cultural Competency \\
\hline Thai- Buddhism & Understand different cultures and join the traditions as appropriate. \\
Thai- Muslim & $\begin{array}{l}\text { Understand different cultures and join the traditions that can be } \\
\text { joined. }\end{array}$ \\
Thai-Chinese & Understand different cultures and join the traditions as appropriate. \\
\hline
\end{tabular}

\section{THE RESULTS}

\section{The Relationship of Acculturation}

The results showed the relationship of acculturation were divided in four aspects that included the deep cultural identity, the two cultural integrating, the three cultural integrating, and the cultural sensitivity. Intensive cultural identities such as religious ceremonies such as merit-making in Thai-Buddhist, fasting in Thai-Muslim, wading through water and fire to enchanting the goddess Lim Ko Niao in ThaiChinese. The combination of two cultures includes certain traditions such as the La Sang ceremony, which consists of
Thai- Buddhist, and Thai -Muslim. Music rituals for healing, observing vegetarianism there are Thai-Buddhist and ThaiChinese. The combining three cultures, such as food, clothing such as using sarong robes, Patek cloths, residences such as fishing. On new year ceremonies such as Songkran in Thai - Buddhist, Hari Raya in Thai-Muslim, and Chinese New Year in Thai-Chinese people. Cultural delicacy to create an understanding of participation in community activities Interfaith activities such as learning about halal food etc (Figure 4).

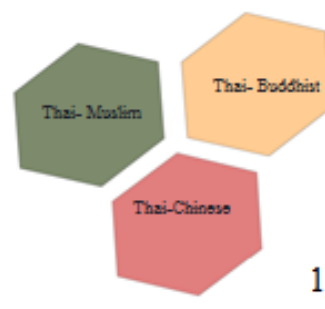

1) Deep cultural identity

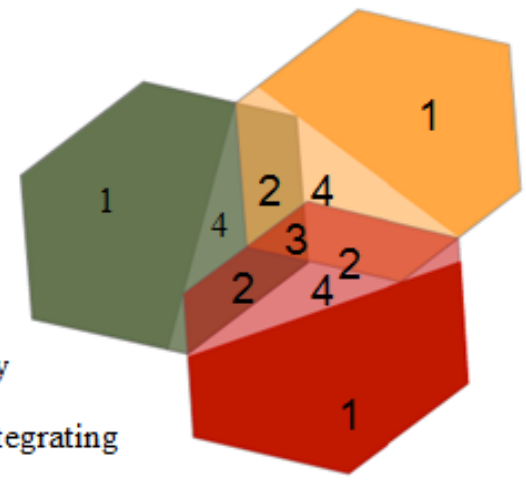

2) The Two Cultural Integrating

3) The Three Cultural Integrating

4) The cultural sensitivity

FIGURE 4. Cultural integration in the three southern borders of Thailand

The Synthesis Elements of the Multicultural Characteristics

The relationship of multicultural in three Southern borders of Thailand revealed that it was synthesis elements is the triple-stranded DNA of the existent three cultures (Figure 5).

The relationship of multiculturalism in three Southern bor- ders of Thailand revealed that it was synthesis elements are the triple-stranded DNA of the existent three cultures. They were connected through Melting Pots theory in two cultural blending and three cultural integrating (Figure 6).

The Salad Bowl theory influenced deep cultural identities, such as religious days and religious rites. The same between culture, but there are different ways (Figure 7).

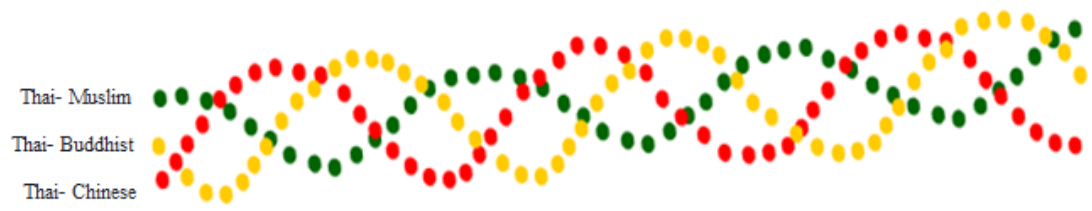

FIGURE 5. Cultural integration in the Triple Helix DNA 


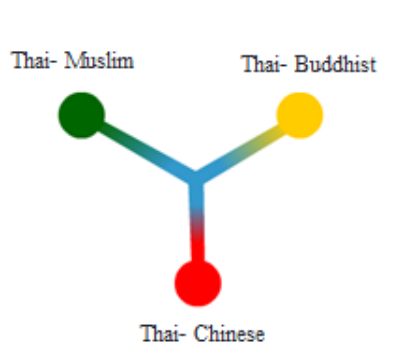

Three cultural integrating

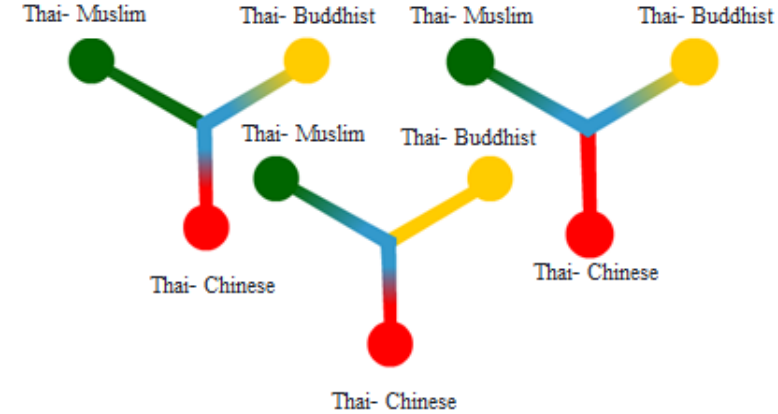

Two cultural integrating

FIGURE 6. The melting Pots of multiculturalism

FIGURE 7. The salad bowl of multiculturalism

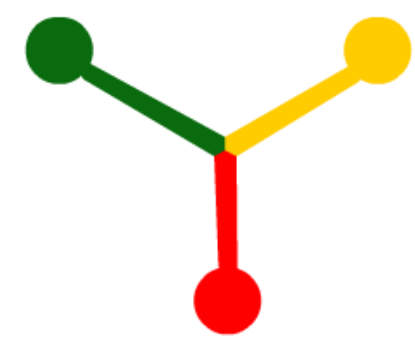

\section{DISCUSSION}

The results of the study show the connection through Melting Pots theory in two cultural blendings and three cultures integrating into cuisines, clothing, medication, language, architecture, occupation, tourist attraction, recreation, inspired person, and craft. This melting pot combination has been showing in multicultural management through surface culture. As a collective art event that creates arts together by multicultural people in Australia, and similar activity is a parafiction Art in Israel and Palestine (Goldber, 2015; Tindle, McCarthy, Lincoln, Lawson, \& Akbar, 2011). In Malaysian, Museum Buildings is the blending of Malaysian architecture, Chinese Peranakan Architecture, and nationalistic European architecture reflects the fusion of cultural integration (Tharazi, Alwi, Anuar, \& Faudzi, 2019). It's like the halal food purchasing by non-Muslims in Singapore share to both Muslims and non-Muslims (Noor, Don, \& Cassidy, 2016). In the Salad Bowl theory influenced deep cultural identities, such as religious days and religious rites. A case study is urban redevelopment planning in Singapore, set up a historic district to show ethnic Singapore that comprises China Town, Little India, and Kampong Glam. Each community represents the uniqueness of its own concentrated culture to promote tourism (Boonyakiet, 2019).

\section{CONCLUSION}

Study based on the original foundations of cultural understanding for the similarities or differences will cause growth in a good way. However, there was a gap between cultures which was part of the cultural sensitivity, for example, the appropriate behavior in the different religious ceremonies that the understanding should be established to connect the triple helix DNA cultures. For example, in Malaysia, multiculturalism is bridging the gap through the Malaysian culture crossing guide. That shows the Malay culture and society as language, culture, customs, and etiquette. For example, the sensitive etiquettes like a meeting and greeting, Malay women may not shake hands with men, The Chinese men and women may shake hands, and Indians shake hands with members of the same sex. The cultural guide to understanding different cultures. The results were the research framework that could be applied in the communication process for bridging the gap between Thai-Buddhist, Thai-Muslim, and Thai-Chinese in three Southern borders of Thailand (Figure 8). 


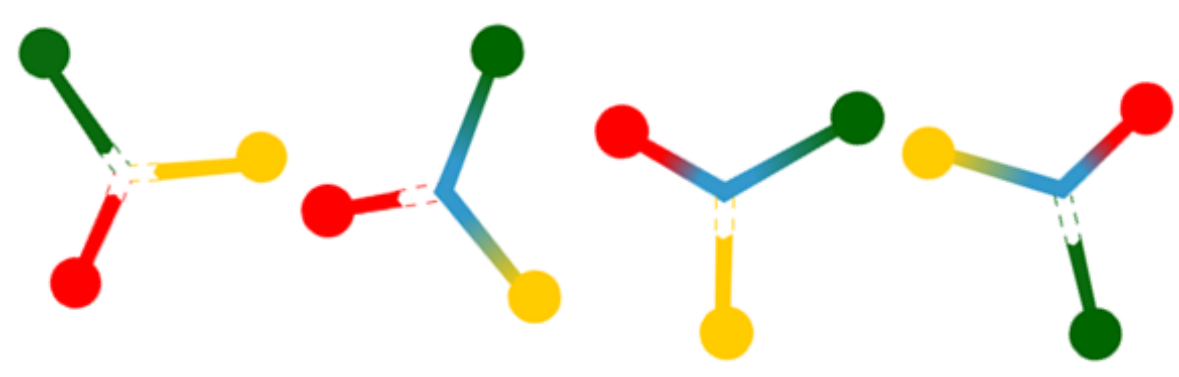

FIGURE 8. Gap between cultures

\section{LIMITATIONS AND RECOMMENDATIONS}

This study has some limitations which must be addressed in future. For instance, time and resource constraints limited the data collection, thus, in future more diverse data from a larger sample must be collected to gather more fine grained results.

\section{REFERENCES}

Ammaphan, S. (1998). Southern native sports (Unpublished master's thesis). Prince of Songkla University, Hat Yai, Thailand. Attharatsathien, P. (2010a). Lungma: The trailer cyclist of pattani. Rusamelae Journal, 31(2), 81-84.

Attharatsathien, P. (2010b). Pattani local food. Rusamelae Journal, 31(1), 96-99.

Berray, M. (2019). A critical literary review of the melting pot and salad bowl assimilation and integration theories. Journal of Ethnic and Cultural Studies, 6(1), 142-151.

Boonyakiet, B. (2019). Formation and transformation of a museum: The national museum of Singapore from colonial period to nation-building era. Journal of Sociology and Anthropology, 38(1), 51-81.

Charoenwattana, B., \& Renumas, M. (2017). Peace way: Conflict management following the peace approach. Journal of MCU Peace studies, 5(2), 1-16.

Chou, P. C., Wu, S. F., \& Chou, Y. C. (2017). The perspective of indigenous culture: A case study of the Truku tribe in East Taiwan. Journal of Advanced Research in Social Sciences and Humanities, 2(1), 67-71. doi:https://doi.org/10.26500/ jarssh-02-2017-0109

College of Islamic Studies Prince of Songkla University, and Yala Islamic College. (2005). The needs of the people in 3 Southern border provinces (Yala, Pattani and Narathiwat provinces) (Technical report). Prince of Songkla University Pattani Campus, Rusamilae, Thailand.

Deep South Incident Database. (2016). Southern border conflict in 13 years: The complexity of the field, the violence and the power of the patani peace dialogue. Retrieved from https://bit. $1 \mathrm{y} / 352 \mathrm{mF} 08$

Duangchan, P. (1984). Music, sports and games of Thai Muslims in the southern border provinces of Thailand (Technical report). Office of the National Culture Commission Ministry of Education, Bangkok, Thailand.

Duerae, S. (2015). The other Chinese within: The story of Chinese in the Malay community in Southernmost of Thailand (Technical report). Thailand Science Research, Bangkok, Thailand.

Eksaphan, U., Intararak, C., Phatyaiying, P., \& Wongmontha, A. (2005). Ethics in daily life of Thai Buddhist in three Southern border provinces: A case study from local wisdom (Technical report). Prince of SongKla University, Pattani, Thailand.

Goldber, G. K. (2015). The melting pot: Parafiction art in Israel and Palestine. Journal of Arts Writing by Students, 1(1), 103-113. doi:https://doi.org/10.1386/jaws.1.1.103_1

Hall, E. T. (1989). Beyond culture. New York, NY: Anchor.

Haryeeyahama, N., \& Punyaburana, O. (2006). The cultural integration among the Buddhist, Chinese and Muslim Thais in Amphoe Muang, Pattani Province (Technical report). Prince of Songkla University, Pattani, Thailand.

Kaewnuy, P. (2013). Integration of Thai Buddhist and Thai Muslim cultures in Lower South Provinces of Thailand (Unpublished master's thesis). Prince of SongKla University. Songkla, Thailand.

Kitthavorn, P. (2004). Cultural diversity and the context of border communities (Technical report). Prince of Songkla University, Pattani, Thailand.

Laosat, A. (1987). Thai monastery mural painting in three Southern Border Provinces of Thailand: A study of its joint influences (Technical report). Prince of SongKla University, Pattani, Thailand. 
Lohajinda, N. (2004). Salt farming development and its trade in Pattani (Technical report). Princess Galyani Vadhana Institite of Cultural Studies, Pattani, Thailand.

Meenium, M., Chitsripiromsri, S., Kuyai, K., Panumamas, P., Uthai, R., Sukpae, J., \& Chanklin, N. (2005). Survey on language usage of teenagers in Southern of Thailand (Technical report). Prince of SongKla University, Pattani, Thailand.

Muhamad, C. (2016). To participate in the promotion of local culture in the deep south sustainable: A case study shows Ma Yong, Muang Pattani (Technical report). Department of Culture Promotion, Bangkok, Thailand.

Noor, N., Don, P. A., \& Cassidy, J. (2016). Factors affecting halal food purchasing by non-Muslims in a multicultural society: A case study in Singapore. International Journal of Islamic Marketing and Branding, 1(4), 366-387. doi:https://doi.org/ 10.1504/IJIMB.2016.081315

Oraphan, P. (2008). Intercultural communication of Malay-Thai in Southen Thailand and Thai -Malaysian in Kelantan, Malaysia (Unpublished doctoral dissertation). Thammasat University, Bangkok, Thailand.

Pan, S., \& Lu, L. (2019). A preliminary study on the cause of conflicts in multidisciplinary collaboration. Journal of Advances in Humanities and Social Sciences, 5(1), 44-53. doi:https://doi.org/10.20474/jahss-5.1.5

Phongphaw, P. (1985). Intergroup relationship between Thai Buddhist and Thai Muslim in Narathivat Province: A case study of social distance (Unpublished master's thesis). Chulalongkorn University, Bangkok, Thailand.

Phromwiset, T. (2013). Dikir hulu lyric: Language value and communication related to society and culture of southern border provinces (Technical report). Department of Cultural Promotion, Bangkok, Thailand.

Pinyomak, K. (2005). Identification of Muslims-Thai and Chinese-Thai in Pattani: Looking through the legend of krue se Mosque. Rusamelae Journal, 26(1), 59-66.

Rattanamanee, P., Lohajinda, N., Hayeehama, N., Punyaburana, O., \& Saengnin, J. (2007). Culture in the three southern border provinces (Pattani, Yala and Narathiwat) (Technical report). Prince of SongKla University, Pattani, Thailand.

Rueangnarong, P. (2010). Folk tales of Southern border provinces. Rusamelae Journal, 31(2), 74-76.

Sariming, N. (1998). A comparative study of the marriage tradition and marriage principles of Islam of Thai Muslim in the Southern border province (Technical report). Prince of SongKla University, Pattani. Thailand.

Sirisakdamkeong, P. (2004). The interrelationship between Malay Muslims and the Chinese in the market place, "Sai Klang", in Yala province (Unpublsihed master's thesis). Silpakorn University, Bangkok, Thailand.

Sirisakdamkeong, P. (2009). Cultural skills. Bangkok, Thailand: The Princess Maha Chakri Sirindhorn.

Tepsing, P., \& Bunprakarn, K. (2016). Local wisdoms in Thailand-Malaysia border culture: A case study of Lohjood community, Narathiwat province. Journal of Yala Rajabhat University, 11(1), 19-38.

Tharazi, M., Alwi, N., Anuar, H., \& Faudzi, Y. (2019). Devil is in the detail: Analysing the ethno-cultural blending in Malaysian museum building. In Expanding the Diversity of intercultural Eastern Art \& Design, Nayoya: Japan.

Thepsuriwong, S. (2004). Thai Muslim local food [25]. (2).

Thepsuriwong, S., \& Buakwan, B. (2004). Collect and analyze the data on folk wisdom of the lower southern Thailand (Technical report). Princess Galyani Vadhana Institite of Cultural Studies, Pattani, Thailand.

Tindle, E., McCarthy, M., Lincoln, D., Lawson, L., \& Akbar, H. (2011). Multicultural melting pot: Painting for the planet. Congruence, 10(3), 28-31.

Watthanakun, C. (1994). Kru-ze: The relationship between ethnicity myth and ritual (Unpublished master's thesis). Chulalongkorn University, Bangkok, Thailand.

Weng, H. Y., \& Yang, C. H. (2016). Culture conservation and regeneration of traditional industries derived by tourism factorycase study of Kwong xi paper factory in Taiwan. International Journal of Humanities, Arts and Social Sciences, 2(5), 172-180. doi:https://doi.org/10.20469/ijhss.2.20003-5

Wiboonma, S., Lohajinda, N., Hayeehama, N., Rattanamanee, P., \& Punyaburana, O. (2007s). Research and development oflocal museum knowledge a case study of the three southern border provinces (Technical report). Princess Galyani Vadhana Institite of Cultural Studies, Pattani, Thailand.

Wongmondta, A. (2015a). Dr. mohamad abdulgader: Biography, concepts, and role in development society of the southern border provinces. Rusamelae Journal, 36(4), 94-99.

Wongmondta, A. (2015b). Intercultural communication of Thai-Malay descent and Malaysian-Thai. Rusamelae Journal, 39(1), 95-98. 